\title{
EFFECTIVITY OF “ANTIMAST" ON BLOOD ANTIOXIDANT PROFILE AND LIPID PEROXIDES CONTENT IN DAIRY COWS WITH SUBCLINICAL MASTITIS
}

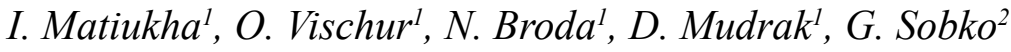 \\ iramatiukha@gmail.com
}

${ }^{1}$ Institute of Animal Biology NAAS,

38 V. Stus str., Lviv 79034, Ukraine

${ }^{2}$ Lviv National University of Veterinary Medicine

and Biotechnologies named after S. Z. Gzhytsky,

50 Pekarska str., Lviv 79010, Ukraine

Research and evaluation of new drug on natural basis in cows with subclinical form of mastitis was conducted. In our investigations we proved significantly positive effects "Antimast" both in the form of injections and "Antimast" ointment on common state of cows with clinical mastitis and on regulation of pro- and antioxidant balance in the organism during treatment.

In this article the action of the injection drug "Antimast" and "Antimast" ointment was established by analyzing the peroxides indexes and antioxidant capabilities in the blood and milk of the bovine cattle. Increasing the intensity of peroxidation reactions as well as lower antioxidant activity in the blood and milk of cows with subclinical mastitis has been discovered. The mean levels of TBARS and lipid hydroperoxides was higher in dairy cows with acute subclinical mastitis compared to the normal indexes in healthy animals indicating a worse state of oxidative stress. After the injection of experimental drug, normalization of the content of oxidative products and in the same time activation of antioxidant enzymes in the blood and milk of the cows were revealed. The same but less pronounced effects of ointment were found.

Both types of "Antimast" played role as activators of endogenic defense system, moreover injection of "Antimast" intracysternaly leads to significant intensively growth of both enzymes compare to ointment ac-

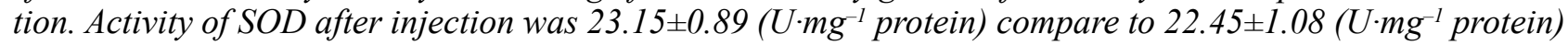
after ointment on the $9^{\text {th }}$ day of treatment.

Keywords: SUBCLINICAL MASTITIS, PRODUCTS OF LIPID PEROXIDATION, ANTIOXIDANT DEFENSE SYSTEM, LIPID HYDROPEROXIDES, OXIDATIVE STRESS

\section{ЕФЕКТИВНІСТЬ ЗАСТОСУВАННЯ «АНТИМАСТУ» НА АНТИОКСИДАНТНИЙ ПРОФІЛЬ КРОВІ ТА ВМІСТ ПРОДУКТІВ ПЕРЕКИСНОГО ОКИСНЕННЯ У КОРІВ ІЗ СУБКЛІНІЧНИМ МАСТИТОМ}

\author{
I. Матюха ${ }^{1}$, О. Вімур ${ }^{2}$ Н. Брода ${ }^{1}$, Д. Мудрак', Г. Собко \\ iramatiukha@gmail.com
}

${ }^{1}$ Інститут біології тварин НААН, вул. В. Стуса, 38, м. Львів, 79034, Україна

${ }^{2}$ Львівський національний університет ветеринарної медицини та біотехнологій імені С. З. Гжицького,

вул. Пекарська, 50, м. Львів, 79010, Україна

Проведено дослідження на коровах з субклінічною формою маститу з метою оичінювання нового препарату на природній основі. У наших дослідженнях виявили позитивний ефект «Антимасту» як препарату для інієкцій, так і мазі «Антимаст» на загальний стан корів з клінічним маститом та регуляцію про- $і$ антиоксидантного балансу в організмі під час лікування.

Дію ін 'єкиійного препарату «Антимаст» та мазі «Антимаст» встановлено методом аналізу продуктів перекисного окиснення та антиоксидантного профілю крові й молока великої рогатої худоби. Встановлено збільшення інтенсивності реакцій перекисного окиснення, а також зниження антиоксидантної активності у крові та молочі корів із субклінічним маститом. Середні рівні ТБК-активних продуктів та ліпідних гідропероксидів були вищими у молочних корів з гострим субклінічним маститом порівняно з циими 
показниками у здорових тварин, щуо свідчить про негативний стан окиснювального стресу. Після введення експериментального препарату вміст окиснювальних продуктів та одночасна активачія антиоксидантних ензимів у крові та молочі корів підтримувалися у фізіологічних межах. Аналогічний ефект, але менш виражений, спостерігали і при застосуванні мазі.

Обидві форми «Антимасту» відіграють роль активаторів ендогенної системи захисту. Ін 'єкція інтрацистернально препарату «Антимаст», порівняно з дією мазі, призводить до збільшення активності

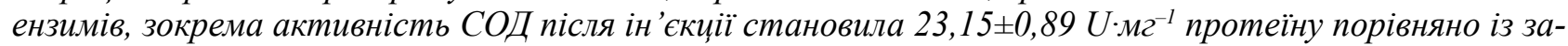

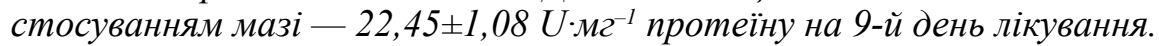

КЛючові слова: СУБКЛІНІЧНИЙ МАСТИТ, ПЕРЕКИСНЕ ОКИСЛЕННЯ ЛІПДІВ, АНТИОКСИДАНТНИЙ ЗАХИСТ, ГІДРОПЕРКИСИ ЛІПІДІВ, ОКСИАТИВНИЙ СТРЕС

\title{
ЭФФЕКТИВНОСТЬ ПРИМЕНЕНИЯ «АНТИМАСТА» НА АНТИОКСИДАНТНЫЙ СТАТУС КРОВИ И СОСТАВ ПРОДУКТОВ ПЕРЕКИСНОГО ОКИСЛЕНИЯ У КОРОВ С СУБКЛИНИЧЕСКИМ МАСТИТОМ
}

\author{
И. Матюха ${ }^{1}$, О. Вищур ${ }^{2}$, Н. Брода, Д. Мудрак, Г. Собко \\ iramatiukha@gmail.com
}

${ }^{1}$ Институт биологии животных НААН, ул. В. Стуса, 38, г. Львов, 79034, Украина,

${ }^{2}$ Львовский национальный университет ветеринарной медицины

и биотехнологий имени С. З. Гжицкого,

ул. Пекарская, 50, г. Львов, 79010, Украина

Проведено исследование на коровах с субклинической формой мастита для оиенки нового препарата на естественной основе. В наших исследованиях установили положительный эффект «Антимаста» как препарата для инъекичй, так и мази «Антимаст» на общее состояние коров с клиническим маститом и регуляцию про- и антиоксидантного баланса в организме во время лечения.

Действие инъекиионного препарата «Антимаст» и мази «Антимаст» установлено методом анализа продуктов перекисного окисления и антиоксидантного профиля крови и молока крупного рогатого скота. Установлено увеличение интенсивности реакций перекисного окисления, а также снижение антиоксидантной активности в крови и молоке коров с субклиническим маститом. Средние уровни ТБК-активных продуктов и липидных гидропероксидов были выше у молочных коров с острыл субклиническим маститом по сравнению с этими показателями у здоровых животньх, что свидетельствует о негативном состоянии окислительного стресса. После введения экспериментального препарата содержание окислительных продуктов и одновременно активачия антиоксидантных энзимов в крови и молоке коров поддерживались в физиологических пределах. Аналогичный эффект, но менее выраженный, отмечено и при применении мази.

Обе формы «Антимаста» играют роль активаторов эндогенной системы зашчиты. Инъекция интрацистернально препарата «Антимаст» по сравнению с действием мази приводит к увеличению

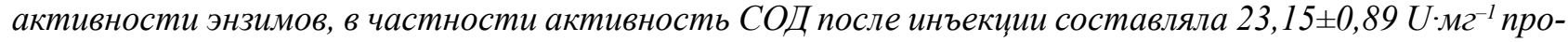

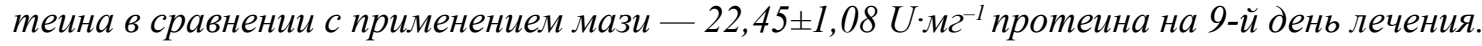

\section{КЛючевЫе слова: СУБКЛИНИЧЕСКИЙ МАСТИТ, ПЕРЕКИСНОЕ ОКИСЛЕНИЕ ЛИПИДОВ, АНТИОКСИДАНТНАЯ ЗАЩИТА, ГИДРОПЕРЕКИСИ ЛИПИДОВ, ОКСИДАТИВНЫЙ СТРЕСС}

Bovine mastitis is considered a major disease that causes economic losses in dairy industry ranging from decrease in milk production to reproductive and metabolic disorders in dairy cows. During mastitis, immune cells in the body recognize invading pathogens and become activated which release inflammatory mediators including nitric oxide, prostaglandins, and cytokines. These mediators promote local inflammation and increased blood flow to the infected tissue, inflammatory cytokines play a key role in stimulating systemic inflammatory responses, including increased body temperature, increased heart rate, and decreased feed intake $[38,36,7]$. In addition, phagocytes produce reactive oxygen species that are needed for killing bacteria during inflammatory process [48]. When the production of oxidants exceeds the capacity of antioxidant defense, a condition of oxidative stress is 
produced resulting in oxidative damage to macromolecules such as lipids, DNA and proteins [8, 29, $41,44,52]$. The oxidative stress may be involved in several pathological conditions including mastitis in dairy animals $[43,6,27]$ which is characterized by an influx of somatic cells, primarily the neutrophils, into the mammary gland. These neutrophils destroy the invading bacteria by oxygen-dependent and oxygen- independent systems. Simultaneously, they potentially damage the secretory epithelium of mammary gland by reactive oxygen species and proteolytic enzymes, resulting in decreased milk production [36]. Although, there are evidences that inflammation of mammary gland may alter the blood oxidative stress parameters in terms of lipid peroxides, reduced glutathione (GSH), vitamin A, $\mathrm{C}, \mathrm{E}$ and trace elements $[21,35]$ but the information on enzymatic antioxidants such as superoxide dismutase (SOD), catalase (CAT) which are the most efficient in directly catalyzing reduction of reactive oxygen species in mastitis is still scanty.

During lactation, mammary epithelial cells exhibit a high metabolic rate and thus produce large amounts of reactive oxygen species and lipid peroxides in vivo. Increased reactive oxygen species level or decreased antioxidants can disrupt the balance between oxidants and antioxidants which is referred to as oxidative stress. This creates a more oxidizing environment that facilitates the binding of pathogens or antigens to effect or cells leading to a hyper-responsive innate immune system and enhanced production of cytokines. Reactive oxygen species can oxidize macromolecules such as lipids, proteins and DNA and cause direct oxidative cell injury or indirectly can modify metabolic pathways [14, 43, 28, 31]. According to mentioned above, it is obvious that peroxidation indexes and antioxidant potential in the living organism are the one of the most informative diagnosis parameters, because all types of stress, including infections and changes in metabolic rate leads to ROS's accumulating and exhausting on defense systems.

Fast and wide spreading of subclinical mastitis causes needs to find effective and safe methods of prevention and treatment of mentioned disease. The aim of presented work was to observe the efficiency of organic drug for injection "Antimast" or ointment "Antimast" on the base of bees propolis in cows with subclinical mastitis.

\section{Materials and methods}

Experimental design. The research was conducted in SE HH "Obroshyno", Pustomyty district, Lviv region during the spring period on two groups of cows ( $2^{\text {nd }}-3^{\text {rd }}$ lactation) with 5-7 animals in each group. Before the investigations cows were diagnosed with the help of viscose metric express method on subclinical forms of mastitis: control group contained clinically healthy animals, research group - animals with signs of subclinical mastitis. To determine the affected breast quarter was used $2 \%$ aqueous solution of mastidine. Cows of the experimental group were administered intracisternally one injection of syringe tube $(13 \mathrm{~mL})$ of the "Antimast" drug for injections (RP number AB-03772-01-12) into the affected udder quarter three times at intervals of 24 hours, into healthy quarter of the breast were prophylactically administered half of the therapeutic dose. Before using the drug milk was milked from all quarters of the udder and the nipple was disinfected. After injection of the drug massages of the breast were performed for its uniform distribution. The drug "Antimast" includes: bee propolis, extract of bee mohr, beeswax, castor oil, vegetable oil. Blood for tests were taken from the jugular vein in cows before injection of the drug and on the $3^{\text {rd }}$ and $9^{\text {th }}$ day after injection. In the blood activity of GPx [33], SOD [24], content of GPH [3], lipid hydroperoxides [32], TBARS and aldehid and ketonic derivatives of protein oxidation [26] were determined. Also some of those indexes in the milk were measured.

The second part of our experiment we performed in the similar way but for treatment the "Antimast" ointment was used. Experiment was conducted in the privat farm "Molochni riky" ("Milk rivers") in the Brodivsky district, Lviv region, on two groups of cows $\left(2^{\text {nd }}-3^{\text {rd }}\right.$ lactation $)$, 5-7 animals in each group. As in the previous experiment, before the investigations cows were diagnosed on subclinical forms of mastitis: control group - clinically healthy animals, research group - animals with signs of subclinical mastitis. Cows of research group after milking once a day, for 7 days were rubbed the "Antimast" ointment into the skin of the udder. In the blood and milk the same indexes as in the first part of investigation were measured. 
Statistical analysis. Results are expressed as mean \pm S.E.M. All variables were tested for normal distribution using the Kolmogorov-Smirnov test $(\mathrm{P}>0.05)$. In order to find significant differences (significance level, $\mathrm{P}<0.05$ ) between groups, the Kruskal-Walliss way analysis of variance by ranks was applied to the data. All statistical analysis was performed by Statistica 8.0 software (StatSoft).

\section{Results and discussion}

In our investigations we proved significantly positive effects of both "Antimast" injection drug and "Antimast" ointment on common state of cows with clinical mastitis and on regulation of pro- and antioxidant balance in the organism during treatment [42]. However, in this material we wanted to compare the effectiveness of "Antimast" in those two forms on the mentioned processes.

In this study, the mean levels of TBARS and lipid hydroperoxides was higher in dairy cows with acute subclinical mastitis compared to the normal indexes in healthy animals indicating a worse state of oxidative stress. As the fig. 1 shows, injection of "Antimast" decreased level of peroxidation products in the blood of cows more intensive than ointment applications.

Glutation peroxidase activity before treatment was lower in sick cows compare to animals of control group (fig. 2). "Antimast" injection of as well as ointment leads to increasing of enzyme activity. However in the case of injection growth of activity was sharper, but at the end of the experiment the level of activity was appropriately equal after the application of "Antimast" in both forms.
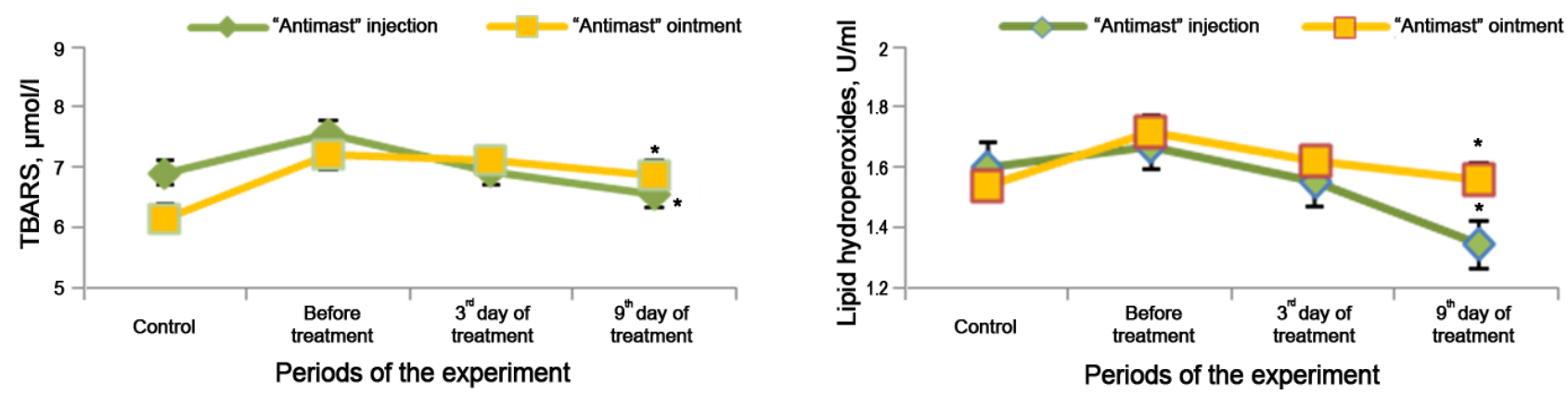

Fig. 1. Intensity of peroxidation processes in the blood of cows

Note: here and further \#- $\mathrm{P} \leq 0.5$, \#\#- $\mathrm{P} \leq 0.1$, \#\#\#- $\mathrm{P} \leq 0.001$ significant differences between types of treatment; $*-\mathrm{P} \leq 0.5, * *-\mathrm{P} \leq 0.1, * * *-\mathrm{P} \leq 0.001$ significant differences between periods of experiment.
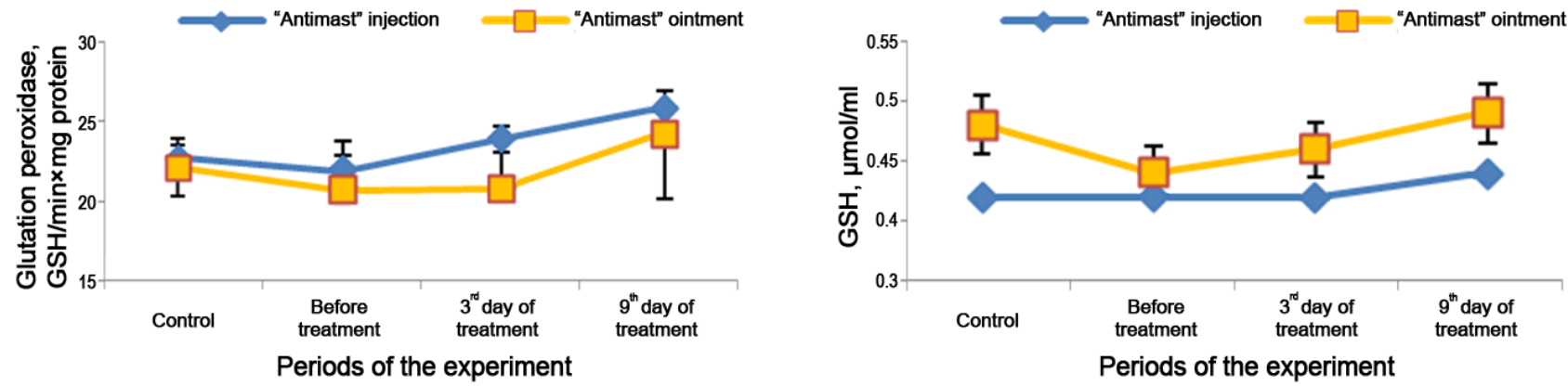

Fig. 2. Activity of glutation system in the blood of cows

Taking in account that in the physiological condition there is negative correlation between the activity of ROS and antioxidant defense system we obviously wanted to measure the enzymes state in the blood of the cows before treatment and after "Antimast" influence (fig. 3).
Thus, significant decreasing of the levels of SOD and catalase activity in both experiments in the blood of dairy cows with subclinical mastitis was established. But both types of "Antimast" played role as activators of endogenic defense system, moreover injection of "Antimast" intracys- 

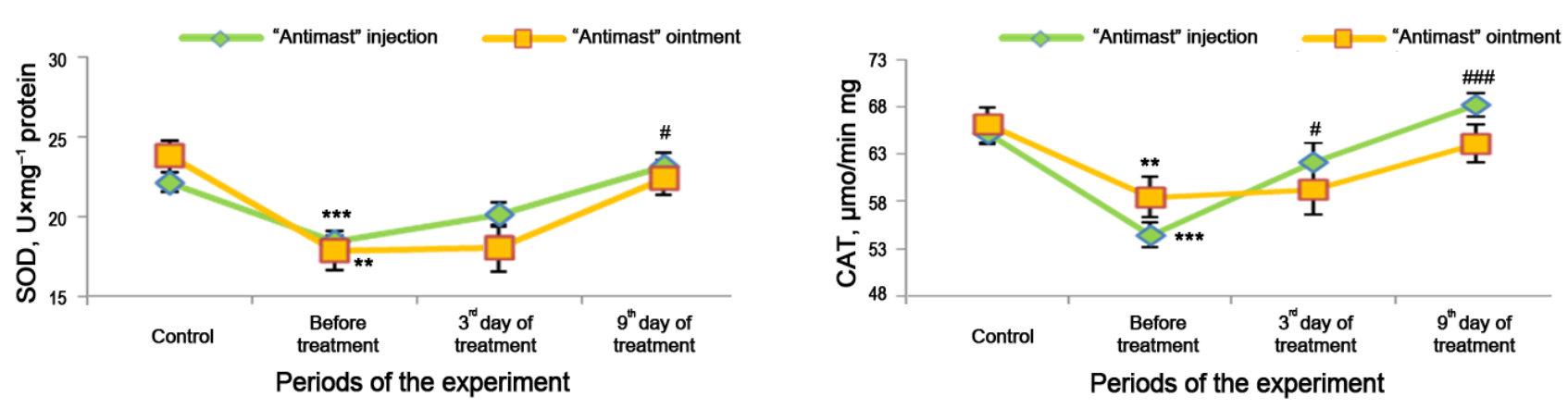

Fig. 3. Activity of superoxiddismutase and catalase in the blood of cows

ternally leads to significant intensively growth of both enzymes compare to ointment action. Activity of SOD after injection was $23.15 \pm 0.89$ (U. $\mathrm{mg}^{-1}$ protein) compare to $22.45 \pm 1.08\left(\mathrm{U} \cdot \mathrm{mg}^{-1}\right.$ protein) after ointment on the $9^{\text {th }}$ day of treatment. Activity of catalase was higher after injection compare to the ointment treatment by $5 \%$ and $6 \%$ on the $3^{\text {rd }}$ and $9^{\text {th }}$ days of experiment, respectively.

Similar indexes in the milk of sick cows were measured. We decide to evaluate level of oxidative processes by content of proteins oxidation derivatives (aldehyde and cetonic) [41]. The degree of protein damage caused by oxidative stress depends on many factors including the nature and relative location of the oxidant or free radical source, the proximity of the radical-oxidant to a protein target, and the nature and concentrations of available antioxidant enzymes and compounds [48]. A number of derivative amino acid side chains have been described in proteins. Some of the most commonly measured protein oxidation products are carbonyl groups. Carbonyl groups have the advantage of being abundant, but they have the disadvantage of being nonspecific oxidation marker [48].

Initiation of oxidation modification of proteins is the most dangerous link of cell damage

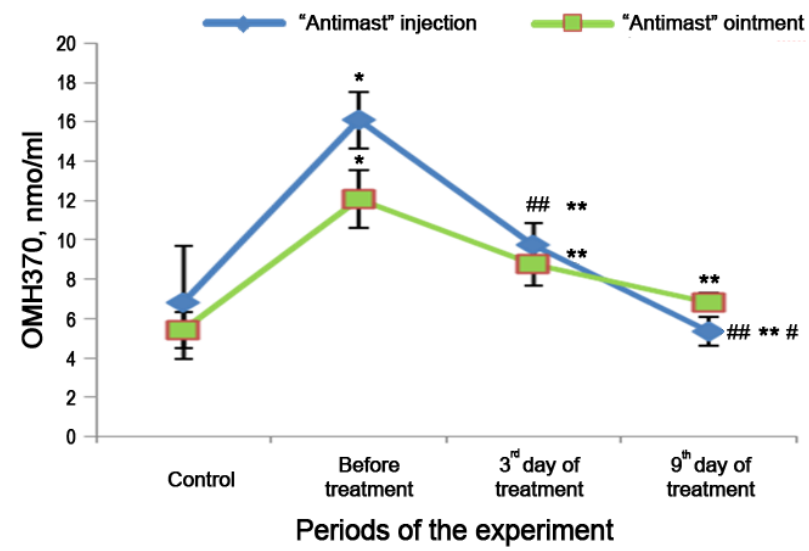

that leads to cytoplasmic enzyme and membrane ion pumps inactivation with different mechanisms gradual initiation of apoptosis. Aldehydic and ketonic derivatives of OMP are very informative indexes; they are more stable than the products of lipid peroxidation [48].

A significant increasing of content $\mathrm{OMP}_{370}$ and $\mathrm{OMP}_{430}$ as reaction on infection stress was established in the milk of sick dairy cows. After using "Antimast" in both forms a significant decreasing the content of protein oxidation derivatives was discovered in the milk of cows from the experimental group. Character of those changes was similar after use of injection and ointment, which indicate the regulative effect of "Antimast" on peroxidation intense (fig. 4).

Investigation activity of superoxiddismutase showed similar action both forms of "Antimast", with one difference: on the $3^{\text {rd }}$ day of treatment "Antimast" drug caused significant rise of enzyme's activity. But on the $9^{\text {th }}$ day activity of SOD was slightly higher than before treatment (fig. 5).

Free radicals are natural end products of the intensive metabolism in cells of the living organism, including high-yielding dairy cows. When the homeostasis is disturbed principally by gen-

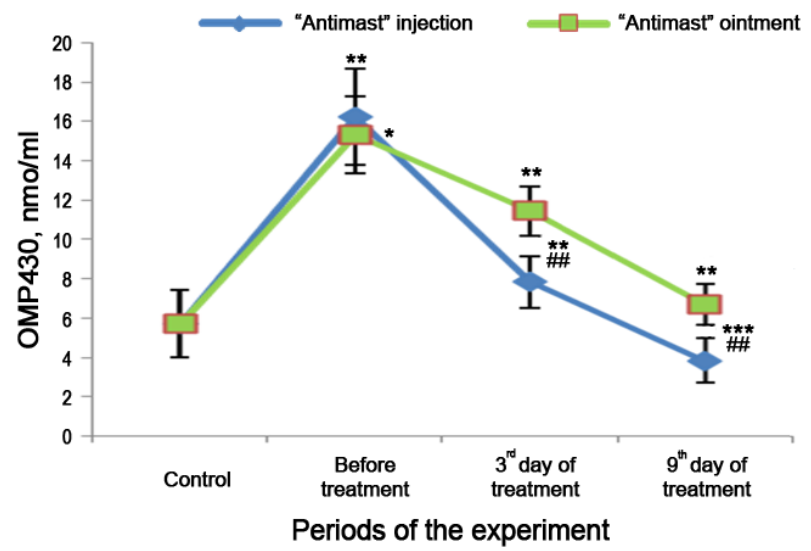

Fig. 4. Intensity of peroxidation processes in the milk of cows 
eration and accumulation of these free radicals, oxidative processes lead to oxidative stress causing mastitis in dairy cows. The inflammation of mammary glands can cause reduction of milk yield and unfavorable changes in the milk composition, e.g. reduction in fat, casein proteins and calcium content with a simultaneous increase in the concentration of whey proteins, sodium and chlorine [15, 17]. Clinically, in dairy cows with acute clinical mastitis, the clinical index score was significantly $(\mathrm{P}<0.05)$ increased in comparison with control group. This could be attributed to inflammation of the mammary glands following their infection which represents the stage at which clinical mastitis occurs with varying degrees of clinical abnormalities of the udder and variable systemic effects with appearance of gross abnormalities of the milk.

Macrophages, neutrophils and other phagocytic cells considered as the potent cells of immune response of mammary glands against microbial infection. Those cells generate large amounts of reactive oxygen species and reactive nitrogen species that considered as the main cause of lipid peroxidation which is used as an indicator of oxidative stress in such tissues. Lipid peroxidation is a well-established mechanism of oxidative damage caused by reactive oxygen species, and measurement of the MDA provides a convenient index of lipid peroxidation.

For our investigation we used two forms of natural, ecologically save and high active preparations which consist of different bees products and subproducts of their action. These bees' biologically activity components are rich in flavonoids, aminoacids, vitamins, minerals etc. All those components have specific directed effect on as antioxidant substances or can act as stimulation for endogenous defense system. As we demonstrated those drug and ointment can increase enzymes activity and slow down intensity of oxidation reactions.

Our results are confirmed by numerous results of other authors, which also showed positive effect from natural preparations in dairy cows with subclinical mastitis $[2,10,12]$. Due to the fact that a close correlation exists between the oxidative status and mastitis in cows a superiority of oxidizing processes can indicate a subclinical inflammation of the mammary gland. Depending on the size of the inflammation one may observe a reduction in milk

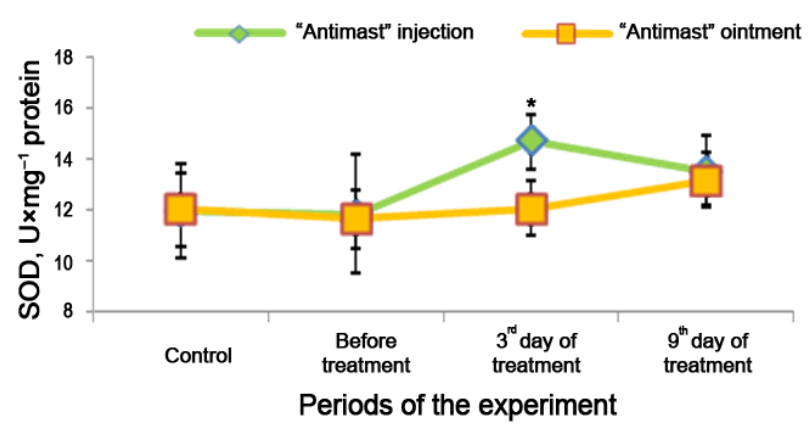

Fig. 5. Activity of superoxiddismutase in the milk of cows

yield and unfavorable changes in the milk composition [16, 44, 45, 46, 47]. In the milk of cows afflicted with mastitis one may observe a reduction in fat, casein proteins and calcium content with a simultaneous increase in the concentration of whey proteins, sodium and chlorine. Moreover, the activity of enzymes from the group of lipases, proteases, oxidases and the plasminogen increases in the milk, negatively affecting its technological properties and eating quality of milk products $[37,44,45$, 46]. In such milk also bacterial enterotoxins may be found. The oxidation processes occurring in milk, beside lowering its nutritive value, have a negative effect on organoleptic parameters, principally taste, and cause the inactivation of many biologically active ingredients contained in it. As a rule, the increase in the number of somatic cells and bacteria in milk accompanies the inflammation of the mammary gland; both these indicators, as mentioned earlier, play a key role in the assessment of milk quality [37]. The most neuralgic period covers the first three weeks after calving, during which cows are especially exposed to the udder inflammation. Disorders appearing during that time can lead not only to a reduction of milk yield, but also adversely affect the health of the entire organism [15-18, 52]. The intensive metabolism observed during this period is accompanied by an increase in the amount of ROS generated, which when appearing in excess in relation to the non-oxidizable potential, can damage cells and tissues [43]. In recent years attempts are made at finding indicators for the evaluation of commercial milk quality that would be: (1) more precise than the SCC criterion applied hitherto, (2) would enable a quick evaluation of the nutritive value and quality of milk, and (3) characterized by a superior quality and fulfilling the systematically growing consumer's demands [52]. 
These findings were in agreement with those previously reported by Jánosi et al. [13]. In other studies it was shown that antioxidant defense system is compromised in dairy cows with acute clinical mastitis, which is evidenced by decreased plasma TAC and increased MDA level, which may indirectly indicate increased whole free radical activity with a resultant increased OSI reflecting the state of oxidative stress in such cases [11]. Glutathione, a thiol-containing tripeptide, in its reduced form (GSH) is present in living cells at high concentrations [8]. Upon reaction with reactive oxygen species, it gets oxidized to glutathione radical which can be regenerated to its reduced form by glutathione reductase [22]. The present study revealed a tendency to decrease in GSH concentration. Reduced glutathione is present in living cells at high concentrations. It becomes oxidized upon reaction with reactive oxygen species to glutathione radical which can be regenerated to its reduced form by glutathione reductase [22].

In this study, the plasma GSH concentration in dairy cows with acute clinical mastitis was decreased compared to control group. The decreased GSH concentration could be explained by the lower activitiy of enzyme glutathione peroxidase (GPx). In contrast, some studies recorded an increase in GSH in dairy cows with acute clinical mastitis. This variation could be attributed to different GPx activity associated with different bacterial pathogens.

Superoxide dismutase (SOD), a copperzinc containing enzymatic antioxidant localized in the cytoplasm of eukaryotic cells, catalyze the dismutation of superoxide radicals to hydrogen peroxide $\left(\mathrm{H}_{2} \mathrm{O}_{2}\right)$ which can be removed by the activity of the catalase and glutathione peroxidase [22].

In our study we confirmed the loss of SOD and CAT activity in sickness cows as reaction of changes in metabolic rate as in the blood so in the milk. Treatment by drug, which consist of bees products, had influence as act direct antioxidant agent and also activated endogenic protection enzymes and non-enzymatics link of antioxidant defense system.

In the other study revealed a significant decrease in SOD activity in cows with mastitis which might be related with low level of zinc in their blood [36]. A significant decrease in catalase activity was also observed which was similar to the finding observed by Sharma et al. in bovine staphylococcal mastitis. The protective effect of catalase has been demonstrated in bovine neutrophil-induced model of mammary cell damage [4].

Using the preparations on the bee's products basis for treatment the inflectional pathologies becomes popular in human and veterinary medicine day by day. But there is small amount of data about the influence of such substances on oxidative processes in dairy cows with subclinical mastitis. Existing experimental data does not explain ways of correction metabolic changes with help of bee's products, which consist of whole complex of substances with bioantioxidant ability.

Fundamental researches of scientists proved high biological value of bee's products (propolis, pollen etc.); they have different pharmacological activity (anesthetic, antimicrobial, antioxidant, immunstilation, inflammatory).

All these facts confirms by our results which we have obtained about the treatment effects of propolis and other bee's products as main components of "Antimast" in both forms. It was experimentally proved that propolis has antioxidant properties. A great part in the "Antimast" content belongs to bioflavonoids and polyphenolic structures with antioxidant action. It was established that bioflavonoids decrease cell-mediate immune reactivity against specific agents of the liver in sick organisms and caution the appearance of free radicals in the lymphocytes [49]. Matolinets used propolis in their studies, which revealed carotene, vitamin $\mathrm{A}$ and $\mathrm{C}$, bioflavonoids, and phenolic compounds. Introduction of propolis caused a positive change in the state of antioxidant system in animals affected by Cadmium. There was a clear tendency to increase the activity of catalase in the liver and SOD under the influence of propolis. Obviously, the positive effect of propolis is due to its tread effect on biological membranes. In addition, activation of the synthesis of enzymes AOS under the influence of propolis may also be significant. The introduction of propolis corrected changes in the concentration of vitamins A and C, both in the blood and in the liver. The slight increase in the activity of the enzymes of the glutathione system is obviously due to the inability of the propolis to compensate for the inhibition of the components of this system [30]. Propolis is a promising raw mate- 
rial for the production of veterinary antimicrobial agents, since it exhibits antimicrobial activity in relation to more than 100 types of bacteria, fungi, viruses and is well combined with chemotherapeutic drugs, enhancing their effect. Biologically active substances in its composition have a certain chemical structure and acting on different mechanisms on microorganisms, which causes the absence of cases of resistance to propolis of strains. The conducted market analysis has shown that there is a need for the creation of combined veterinary drugs with substances of natural origin [25].

The presence of propolis as the most biological active compound in the "Antimast" explains the results we received about its effect on the state of the antioxidant profile, which is also supported by literary data [53].

\section{Conclusion}

The present study was conducted to evaluate the effects of "Antimast" in both forms of ointment and injection. The experimental data on the influence of the "Antymast" drug which contains bees propolis, extract of bees "pidmor", beeswax, castor oil, plant oil on the level of the products of lipid peroxidation (LPO) and the state of antioxidant protection in the blood of cows suffering from subclinical form of mastitis. Conducted studies showed that plasma levels of sick cows TBARS were higher than in clinically healthy animals. Studies found that use of "Antymast" for sick cows causes decrease of plasma concentrations of TBARS and hydroperoxides lipids compared to the period before drug administration. There tends to increase glutathioneperoxidase activity and glutathione content in blood of cows investigated drug. Normalization of level protein destruction by reactive oxygen species and its derivatives we established in the milk of sick cows after treatment.

Perspectives of the future investigations. Obtained results convinced us that finding the most optimal methods of prevention and treatment of subclinical mastitis has to be devoted to the exploration of substances with direct antioxidant effect. Exactly we will develop this question further.

1. Bagnicka E., Winnicka A., Jóźwik A., Rzewuska M., Strzałkowska N., Kościuczuk E., Prusak B., Kaba J., Horbańczuk J., Krzyżewski J. Relationship be- tween somatic cell count and bacterial pathogens in goat milk. Small Ruminant Research, 2011, vol. 100, no. 1, pp. 72-77. DOI: 10.1016/j.smallrumres.2011.04.014.

2. Batracov A. Ja. Treatment and prevention of mastitis in cows. Veterenary, 1977, vol. 2, pp. 68-69. (in Russian)

3. Beutler E., Dubon O. B., Kelly M. Improved method for the determination of blood glutathione. Journal of Laboratory and Clinical Medicine, 1963, vol. 61, pp. 882-888.

4. Boulanger V., Zhao X., Lacasse P. Protective Effect of Melatonin and Catalase in Bovine Neutrophil induced Model of Mammary Cell Damage. J. Dairy Sci., 2002, vol. 85, no 3, pp. 562-569. DOI: $10.3168 /$ jds.S0022-0302(02)74109-X.

5. Bozukluhan K., Atakisi E., Atakisi O. Nitric oxide levels, total antioxidant and oxidant capacity in cattle with foot-and-mouth-disease. Kafkas. Univ. Vet Fac. Derg., 2013, vol. 19, no 1, pp. 179-181. DOI: $10.9775 / \mathrm{kvfd} .2012 .7244$.

6. Celi P. The role of oxidative stress in small ruminants' health and production. R. Bras. Zootec., 2010, vol. 39, pp. 348-363. DOI: 10.1590/S151635982010001300038 .

7. Dantzer R., Kelley K. W. Twenty years of research on cytokine-induced sickness behavior. Brain Behav. Immun., 2007, vol. 21, no. 2, pp. 153-160. DOI: 10.1016/j.bbi.2006.09.006.

8. Halliwell B., Gutteridege J. M. C. Free Radicals in Biology and Medicine. $4^{\text {th }}$ ed. Midsomer Norton, Avon, England, Oxford University Press, 2007.

9. Halliwell B., Gutteridge J. M. C. Free Radicals in Biology and Medicine. $3^{\text {rd }}$ ed. New York, Oxford University Press, 1999.

10. Havsteen B. H. The biochemistry and medical significance of the flavonoids. Pharmacol. Therap., 2002, vol. 96, no. 2-3, pp. 67-202. DOI: $10.1016 /$ S0163-7258(02)00298-X.

11. Ibrahim H. M. M, El-seedy Y. Y, Gomaa N. A. Cytokine Response and Oxidative Stress Status in Dairy Cows with Acute Clinical Mastitis. J. Dairy Vet. Anim. Res., 2016, vol. 3, no. 1, 00064. DOI: 10.15406/ jdvar.2016.03.00064.

12. Jakovleva L. V., Avdeeva I. I. Tratment of experimental proctytis by suposytors "Proprofen". Clinical Pharmacia, 2000, vol. 4, no. 2, pp 46-50. (in Russian)

13. Jánosi S., Kulcsár M., Kóródi P., Kátai L., Reiczigel J. Energy imbalance related predisposition to mastitis in group-fed high-producing postpartum dairy cows. Acta Vet. Hung., 2003, vol. 51, no. 3, pp. 409424. DOI: 10.1556/AVet.51.2003.3.14.

14. Jin L., Yan S. M., Shi B. L., Bao H. Y., Gong J. Effects of vitamin A on the milk performance, antioxidant functions and immune functions of dairy cows. Animal Feed Science and Technology, 2014, vol. 192, pp. 15-23. DOI: 10.1016/j.anifeedsci.2014.03.003.

15. Jóźwik A., Krzyżewski J., Strzałkowska N., Poławska E., Bagnicka E. Relations between the oxidative status, mastitis, milk quality and disorders 
of reproductive functions in dairy cows. A review. Animal Science Papers and Reports, 2012, vol. 30, no. 4, pp. 297-307.

16. Jóźwik A., Śliwa-Jóźwik A., Strzałkowska N., Krzyżewski J., Kołątaj A. Relationship between somatic cell count, level of GSH, milk yield and its chemical composition. Medycyna Weterynaryjna, 2004, vol. 60, no. 11, pp. $1215-1217$.

17. Jóźwik A., Strzałkowska N., Bagnicka E., Grzybek W., Krzyżewski J., Poławska E., Kolataj A., Horbańczuk J. O. Relationship between milk yield, stage of lactation and some blood serum metabolic parameters of dairy cows. Czech Journal of Animal Science, 2012b, vol. 57, no. 8, pp. 353-360. DOI: 10.17221/6270-CJAS.

18. Jóźwik A., Strzałkowska N., Bagnicka E., Łagodziński Z., Pyzel B., Chyliński Jóźwik A. Oxidative status in highly productive dairy cows as related to milk yield, lactation stage and Somatic Cell Count. Prace i Materiaty Zootechniczne. Monografie i Rozprawy, 2010, vol. 23, pp. 7-111. (in Polish)

19. Kamushnikow V. S. Handbook in the clinical and biochemical investigations and laboratory diagnostic. Moscow, Medpressinform, 2004, 820 p. (in Russian)

20. Khismatulina N. Z. Apitherapy. Perm, Mobile, 200, pp. 49-67. (in Russian)

21. Kizil O., Akar Y., Saat N., Kizil M., Yuksel M. The plasma lipid peroxidation intensity (MDA) and chain- breaking antioxidant concentrations in the cows with clinic or subclinic mastitis. Revue Méd. Vét., 2007, vol. 158 , no. 11 , pp. 529-533.

22. Kohen R., Nyska A. Oxidation of biological systems: oxidative stress phenomena, antioxidants, redox reactions, and methods for their quantification. Toxicol. Pathol., 2002, vol. 30, pp. 620-650. DOI: 10.1080/01926230290166724.

23. Koroliuk M. A., Ivanova L. I., Maǐorova I. G., Tokarev V. E. A method of determining catalase activity. Lab. Work, 1988, vol. 1, pp. 16-19. (in Russian)

24. Kostiuk V.A., Potapovich A. I., Kovaleva Zh. V. A simple and sensitive method of determination of superoxide dismutase activity based on the reaction of quercetin oxidation. Questions of Med. Chem., 1990, vol. 36, no. 2, pp. 88-91. (in Russian)

25. Kovalyova O. O., Tikhonov O. I. Prospects for the creation of combined veterinary drugs for the treatment of endometritis in cows. Actual problems of modern medicine technology and extemporal formulation, 2007, vol. 1, pp. 386-387. (in Russian)

26. Levine R. L., Garland D., Oliver C. N., Amici A., Climent I., Lenz A. G., Ahn B. W., Shaltiel S., Stadtman E. R. Determination of carbonyl content in oxidatively modified proteins. Methods Enzymol., 1990, vol. 186, pp. 464-478. DOI: 10.1016/00766879(90)86141-H.

27. Lykkesfeldt J., Svendsen O. Oxidants and antioxidants in disease: Oxidative stress in farm animals. Vet. J., 2007, vol. 173, pp. 502-511. DOI: 10.1016/j. tvj1.2006.06.005.
28. Maddox J. F., Aherne K. M., Reddy C. C., Sordillo L. M. Increased neutrophil adherence and adhesion molecule mRNA expression in endothelial cells during selenium deficiency. J. Leukoc. Biol., 1999, vol. 65, no. 5, pp. 658-664. DOI: 10.1002/jlb.65.5.658.

29. Marnett L. J. Lipid peroxidation-DNA damage by malondialdehyde. Mutat Res, 1999, vol. 424, no. 1-2, pp. 83-95. DOI: 10.1016/S0027-5107(99)00010-X.

30. Matolienec O. M. Age features of antioxidant and immune systems in animals with cadmium intoxication and their correction with antioxidants and enterosorbents. Phd of medical sciences thesis, Ternopil State Medical Academy named after I. Gorbachevsky, 2000. (in Ukrainian)

31. Miller J. K., Brzezinska-Slebodzinska E., Madsen F. C. Oxidative stress, antioxidants, and animal function. J. Dairy Sci., 1993, vol. 76, no. 9, pp. 2812-2823. DOI: $10.3168 /$ jds.S0022-0302(93)77620-1.

32. Mironchik V. The method of measurement of lipid hydroperoxides in biological material. Official Buletin, 1984, vol. 13, p. 2.

33. Moin V. A simple and specific method for determining glutathione peroxidase activity in erythrocytes. Lab. Work, 1986, vol. 12, pp. 724-727. (in Russian)

34. Nielsen F., Mikkelsen B. B., Nielsen J. B., Andersen H. L., Grandjean P. Plasma malondialdehyde as a biomarker for oxidative stress: reference interval and effects of life style factors. Clin. Chem., 1997, vol. 43, no. 7, pp. 1209-1214.

35. Omarow Sh. M. Apitherapy: the products of apiculture in the world of medicine. Rostov-on-Don, Phoenix, 2009, pp. 78-95. (in Russian)

36. Ranjan R., Swarup D., Naresh R., Patra R. C. Enhanced erythrocytic lipid peroxides and reduced plasma ascorbic acid, and alteration in blood trace elements level in dairy cows with mastitis. Vet. Res. Commun., 2005, vol. 29, pp. 27-34. DOI: 10.1023/B:VERC. $0000046740.59694 .5 \mathrm{~d}$.

37. Santos J. E., Cerri R. L., Ballou M. A., Higginbotham G. E., Kirk J. H. Effect of timing of first clinical mastitis occurrence on lactational and reproductive performance of Holstein dairy cows. Anim. Reprod. Sci., 2004, vol. 801, no. 2, pp. 31-45. DOI: 10.1016/S03784320(03)00133-7.

38. Sawa A., Neja W., Bogucki M. Relationships between cytological quality and composition of milk and the effect of some environmental factors on the frequency of recurrent mastitis in cows. Journal of Central European Agriculture, 2008, vol. 8, pp. 295-300.

39. Seegers H., Fourichon C., Beaudeau F. Production effects related to mastitis and mastitis economics in dairy cattle herds. Vet. Res., 2003, vol. 34, no. 5, pp. 475-479. DOI: $10.1051 /$ vetres:2003027.

40. Sharma N., Mukherjee R., Ingale S. L., Jadhav R. K. Therapeutic and anti-oxidant activity of vitamin $\mathrm{E}$ and selenium in bovine Staphylococcal mastitis. Indian J. Vet. Res., 2010, vol. 19, no 1, pp. 25-31.

41. Shtapenko O., Matiukha I., Hevkan I., Tkachenko H. The influence of trace elements in liposomal com- 
pounds on oxidative stress markers in the reproductive organs of female rabbits. Stupskie Prace Biologiczne, 2015, vol. 12, pp. 173-186.

42. Siems W. G., Grune T., Esterbauer H. 4-Hydroxynonenal formation during ischemia and reperfusion of rat small-intestine. Life Sci., 1995, vol. 57, pp. 785-789. DOI: 10.1016/0024-3205(95)02006-5.

43. Sobko G. M., Broda N. A., Vishchur O. I., Kurtiak B. M. Influence of "Antymast" on the system of antioxidant defense of cows with subclinical form of mastitis. Scientific bulletin of LNUVMBT named after S. Z. Gzhytsky, 2016, vol. 18, no. 65, pp. 158-163. (in Ukrainian)

44. Sordillo L. M., Aitken S. L. Impact of oxidative stress on the health and immune function of dairy cattle. Vet. Immunol. Immunopathol., 2009, vol. 128, no. 1-3, pp. 104-109. DOI: 10.1016/j.vetimm.2008.10.305.

45. Stadtman E. R. Role of oxidant species in aging. Curr. Med. Chem., 2004, vol. 11, pp. 1105-1112. DOI: $10.2174 / 0929867043365341$.

46. Strzałkowska N., Jóźwik A., Bagnicka E., Krzyżewski J., Horbańczuk J. O. Studies upon genetic and environmental factors affecting the cholesterol content of cow milk. I. Relationship between the polymorphic form of beta-lactoglobulin, somatic cell count, cow age, stage of lactation and cholesterol content of milk. Animal Science Papers and Reports, 2009a, vol. 27, no. 2, pp. 95-103.

47. Strzałkowska N., Jóźwik A., Bagnicka E., Krzyżewski J., Horbańczuk J. O. Studies upon genetic and environmental factors affecting the cholesterol content of cow milk. II. Effect of silage type offered. Animal Science Papers and Reports, 2009, vol. 27, no. 3, pp. 199-206.

48. Strzałkowska N., Jóźwik A., Bagnicka E., Krzyżewski J., Horbańczuk K., Pyzel B., Słoniewska D.,
Horbańczuk J. O. The concentration of free fatty acids in goat milk as related to the stage of lactation, age and somatic cell count. Animal Science Papers and Reports, 2010, vol. 28, no. 4, pp. 389-395.

49. Thannickal V. J., Fanburg B. L. Reactive oxygen species in cell signaling. Am. J. Physiol. Lung Cell Mol. Physiol., 2000, vol. 279, no. 6, pp. 1005-1028. DOI: 10.1152/ajplung.2000.279.6.L1005.

50. Tykhonov A. I., Tykhonova S. A., Jarnukh T. G. Flower pollen in the pharmacy and medicine. Kharkiv, NPhU, 2006, 308 p. (in Russian)

51. Tykhonov A. I., Tykhonova S. A., Yarnukh T. G. Natural honey in the medicine and pharmacy (origin, properties, usage, medical drugs). Kharkiv, Original, 2010, 263 p. (in Russian)

52. Valko M., Rhodes C. J., Moncol J., Izakovic M., Mazur M. Free radicals, metals and antioxidants in oxidative stress-induced cancer. Chem. Biol. Interact., 2006, vol. 160, pp. 1-40. DOI: 10.1016/j. cbi.2005.12.009.

53. Wang M. Y., Dhingra K., Hittelman W. N., Liehr J. G., de Andrade M., Li D. H. Lipid peroxidationinduced putative malondialdehyde - DNA adducts in human breast tissues. Cancer Epidemiol. Biomarkers Prev., 1996, vol. 5, pp. 705-710.

54. Weiss W. P. Antioxidant nutrients, cow health, and milk quality. Pennsylvania State Dairy Cattle Nutrition, Workshop, 2005, pp. 11-18.

55. Yakovleva L. V, Avdeyeva I. I. Treatment of experimental proctitis with suppositories "Propofen". Clinical Pharmacy, 2000, vol. 4, no. 2, 46-50. (in Russian)

56. Zhao X., Lacasse P. Mammary tissue damage during bovine mastitis: Causes and control. J. Anim. Sci., 2008, vol. 86, no. 1, 57-65. DOI: $10.2527 /$ jas.2007-0302. 